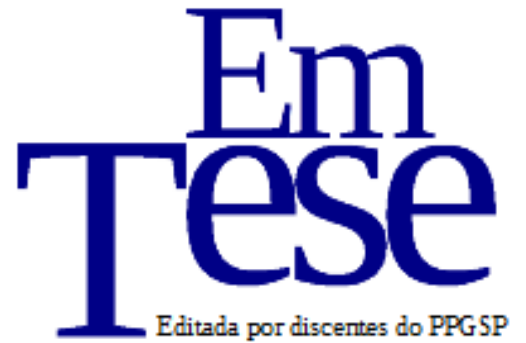

UFSC

PPG SP PROG RAMA DE

POS-GRADUAÇÃO EM

Sociologia

Política

V. 15 , n. 2 p. 01, Julho, 2018.

DOI: http://dx.doi.org/10.5007/1806-5023.2018v15n2p163

\title{
ECHR: An analysis from perspectives of inclusion and the recognition of differences in identity ${ }^{1}$
}

Vanessa Capistrano Ferreira ${ }^{2}$

\begin{abstract}
Based on a factual analysis of cases of racism (Article 14 of the ECHR) tried by the European Court of Human Rights, this study seeks to identify the current limits to the promotion of social inclusion and the recognition of differences in Europe. Within the perspective of Jürgen Habermas's Reconstructive Theory of Law and Axel Honneth's Theory of Recognition, we are able to dispute the supposedly exclusivist application of human rights in Europe through the exposure of jurisprudential failings, which have substantially compromised their effectiveness and democratic legitimacy within the social sphere. We will also argue for the consequences of a system of rights put into effect and legitimized by the particularistic means of a majority-Western culture that hides the arbitrariness and oppression to which continually inferiorized groups not included in modern law are subjected.
\end{abstract}

Keywords: ECHR, Inclusion, Recognition, Emancipation.

\section{ECHR: Uma análise a partir de perspectivas de inclusão e reconhecimento de diferenças de identidade}

Resumo: A partir da análise factual dos casos de racismo (artigo 14 da CEDH) julgados pelo Tribunal Europeu dos Direitos Humanos, este trabalho pretende identificar os atuais quadros limítrofes de promoção da inclusão social e do reconhecimento das diferenças na Europa. Sob a perspectiva da Teoria Reconstrutiva do Direito de Habermas e da Teoria do Reconhecimento de Honneth, será possível contestarmos a aplicação exclusivista dos direitos humanos na Europa, com a exposição de suas lacunas jurisprudenciais, as quais comprometem, em sentido substantivo, sua efetividade e legitimidade democrática no escopo social. Arguir-se-ão, ainda, os efeitos colaterais de um sistema de direitos efetivado e legitimado pelas vias particularistas de uma cultura ocidental majoritária, que silencia a arbitrariedade e a opressão a que são submetidos grupos constantemente inferiorizados e não incluídos no direito moderno.

Palavras-chave: TEDH, Inclusão, Reconhecimento, Emancipação.

\footnotetext{
Esta obra está licenciada com uma Licença Creative Commons Atribuição 4.0 Internacional.

${ }^{2}$ A Brazilian Ph.D. student in the International Relations subject from the Interinstitutional Postgraduate Program of the International Relations course taught at "San Tiago Dantas" College (UNESP, UNICAMP, PUCSP). Agências de fomento: Fundação de Amparo à Pesquisa do Estado de São Paulo (FAPESP). E-mail: capistrano.vanessa@gmail.com
} 


\section{Introduction}

In 1950, with radicalisation of the concepts of freedom, equality, and dignity, the European Convention on Human Rights (ECHR) was signed within the Council of Europe, aiming at assuring "the universal and effective recognition and observance of the Rights" (EUROPEAN, 1950, p. 05) of man, fostering European unity and economic and social progress. The convention became a mechanism of universal recognition of the condition of human equality, seeking the protection and development of human rights, which became the true bases of justice within a democratic regime.

To the incipient role of classic individual rights within the ECHR, discussions regarding economic, social and cultural rights were incorporated, with the addition of the legal-formal European Social Charter in 1961 and Additional Protocols in 1988. However, its most famous contribution was through the creation of agencies intended to judge and execute sentences regarding the transgression of human rights in Europe through the European Court of Human Rights and the Committee of Ministers, respectively.

Regarding the competencies of the Court, since it was created in 1959, one may cite the preservation of values inspired by the rule of law (beyond its restrictive national projects), the defence of pluralist democracy and the protection of human rights and basic freedoms. Its application extends to all citizens of party States that constitute the Council of Europe and to non-citizens who reside in its jurisdictional area (BATTJES et al., 2009). In sum, the Court is presented as a representative agency of universal values and the validation of human rights under the form of full exercise of a trans-national citizenship model.

However, the infirmity of optimism may be perceived when we analyse the jurisprudence of the Court, presented through official documents and as part of specialised literature. The critical study of this material provides for the observation of possible legal omissions in cases that involve the laws and policies of non-discrimination linked to minority groups on the continent. Following Battjes et al. (2009)' argument, the situation of foreigners and non-citizens still varies with diverse notions of identity found within national states, in ethnic and cultural values, races, creeds, and different degrees of national loyalty.

The cases of Sander $v$ United Kingdom (Application $\mathrm{n}^{\circ}$ 34129/96) and Nachova $v$ Bulgaria (Application $\mathrm{n}^{\circ} 43577 / 98$ and 43579/98) are presented in the Factsheet -Racial Discrimination as important decisions in combating racism in Europe; these cases, among other cases, serve as a way of strengthening “democracy's vision of a society in which diversity is not perceived as a threat but as a source of enrichment" (EUROPEAN, 2013). In 
agreement with this conduct, some of the principal jurisprudential standards that make up the basis of development of the history of this Court were also included in the Country Fact Sheets (1959-2010). Under the right of non-discrimination (Article 14 of the ECHR) we find references, among others, to decisions of Velikova $v$ Bulgaria (Application $\mathrm{n}^{\circ}$ 41488/98) and Anguelova v Bulgaria (Application $\mathrm{n}^{\mathrm{o}}$ 38361/97). With regard to these, Dembour (2009) presented various criticisms of the jurisprudence of the Court in combating discrimination on the continent. According to her, in spite of these decisions having been commonly assessed as examples of success in the battle against discrimination, they were transformed into an "elaborate juridical technique that have paradoxically produced (...) the possibility and the need to silence racism" (DEMBOUR, 2009, p. 223). They represent controversial cases since they show themselves to be "blind to racial tensions that still mark European societies" (BATTJES et al., 2009, p. 203).

Using this sample, we discuss the basic foundation of human rights as to their ideal and universal applicability, responsible for creating a project based on the recognition of socio-cultural pluralism in the consolidation of venues of struggle for the preservation of human dignity and in the defence of social contexts free of asymmetric relations of power. We indicate possible socio-normative hindrances included in human recognition, which is continually subjugated by cultural biases and ethnocentric evils recurrent in the Western tradition.

This study tests the hypothesis that traditional frameworks are present in the deliberations of the court. This hinders not only the egalitarian premises existing within the political-philosophical conception of the democratic rule of law but also, principally, return of attention to the solidarity of social links based on recognition of the specificities of each and every person, without which inferiorisation occurs. This condition is essential for the realisation of individual autonomy, which is the basis of constructing and developing the key parameters of the modern system of rights.

In sum, this study analyses, through the method of rational reconstruction and normative reconstruction, the possible implications of the jurisprudential practices of the European Court - in terms of the struggle against discrimination on the continent - which treat prerogatives presumably in the exclusivist application of rights, which weakens its ideal of universality, making it controversial in increasingly complex societies. 


\section{Human rights and the paradox of universality}

Illuminist philosophy of the XVIII century introduced the perspectives of universality and inclusion in terms of human rights. Many philosophers, such as Voltaire, Rousseau, Diderot, Grotius, Kant, Locke and Montesquieu, constructed a transcendental basis for creating a human political community that could extend beyond the territorial limits of European states and Christian history.

The acceptance that all human beings possess rights due to their essential equality as beings possessing reason - came to define a growing constellation of values. However, despite their key elements defending universalism in the concession of rights, protection, guarantees, the preservation of equality, freedom and human dignity, a new model of privileges was created. Within western political communities, relations of equality were established among those who were included, simultaneously excluding most of the population from public subjects: for no peasant, plebs, slave, woman or indigenous person could have the education or freedom necessary to be included among the equal (GIESEN, 2001).

The existing duality between the prerogatives of universal human rights of unlimited scope and the rights of citizens (based on static markers and binary oppositions - such as we/them, native born/foreigners, citizens/non-citizens) influenced a large part of discussions regarding the modern system of rights. Among the classical theorists are Marshall, Berlin, Dworkin, Mill, Rawls, Walzer, Taylor and others. These individuals presented important contributions regarding the recurring struggles between freedom and equality, without losing from view the demands of justice and of community belonging (KYMLICKA; NORMAN, 1994).

The theory of rights largely focuses on the conduct of citizens, varying from demands for community passivity and/or active participation to their responsibilities, roles and loyalties. The emphasis on civic virtue aided the legal production of new and more radical distinctions within social contexts. As Santos (2007) indicated, both in the area of knowledge and modern law, the same underlying distinctions of the colonial era were maintained; that is, the existence of differences between those considered to be friends and enemies. Despite historic conquests, for each new instituted right, exclusion was structurally perpetuated. According to Santos (2012), the theory of law demonstrates the continued weight of exclusions and of decadence within the very perspectives of universality and inclusion.

Within this context, human rights came to be conceived at times as the fruit of demands of privileges, at times as alternative forms of a utopian universalism, with this being 
one of the principal motives for the ineffectiveness of contemporary systems of protection. At times, human rights became instruments of a particularistic cultural artefact that only Western culture tended to formulate as universal (SANTOS, 1997), when in fact nothing more was intended than legitimating their positions of hegemonic power to the detriment of minority groups.

However, when we analyse human rights from the perspective of moral demands, these end up being primordial venues for the achievement of human dignity that support, above all, the hope of a horizon based on the grammar of inclusion, reflecting the emancipatory platform of our time (PIOVESAN, 2005). Santos (1997) also emphasised the importance of not reducing the scientific study to what is most concrete, for otherwise, "we become obliged to justify what actually exists, however unjust or oppressive it may be" (SANTOS, 1997, p. 122).

Having the possibilities of realising its emancipatory potential as a basis, founded on the ideal of social justice and recognition of the other, Jürgen Habermas (1997) presented a reconstructive model of a system of rights that fulfils its role of connecting the imminent tensions of modern society, regarding the dilemmas of universalism $\mathrm{v}$ particularism, freedom $\mathrm{v}$ equality and public autonomy $\mathrm{v}$ private autonomy present in fundamental human rights, which are still compatible with the presuppositions of popular sovereignty, the rule of law and deliberative democracy. It aims at the re-establishment of rights able to lead to a new juridical-democratic praxis, considering historical and social transformations of its contexts of application.

Habermas (2000a) considered legal norms, based on the guarantee of fundamental rights, as coercive laws (due to their inevitable obligatory nature) and laws of freedom (due to their ethical content of symmetric interests of all). Only the preservation of these two spheres can lead to the legitimisation of law, which makes viable the equal preservation of the autonomy of all people, independent of their customs and/or traditions.

For Habermas (2000a), the particular feature of human rights is based on the complementarities between the right and the moral; that is, they are juridical standards that are moral standards simultaneously. The author sees them as the head of Janus, with one face pointing toward positive right and the other one pointing toward moral. In its moral aspect, it expresses the universal substance of the human dignity of every person and the premise of equal access to law due to the human condition of possessing existential uniqueness.

However, the moral content of human rights cannot satisfy its functional imperative in the scope of applicability to modern societies; it is only able to justify it symmetrically and 
indivisibly. Just like in moral, law should equally preserve the autonomy of all, demonstrating beyond legitimacy itself, its aspect of guarantor of freedom. For him, "autonomy, which in the moral field is monolithic, appears in the field of law only under the dual form of public and private autonomy" (HABERMAS, 2000a, p. 290).

The public autonomy of citizens acquires its form in the historical and social organisation of an ethical-political community, ruled by communicative action and the demands of reciprocal recognition, attributing to itself its own laws through the exercise of the sovereign will of the people. In contrast, the sphere of private autonomy is charged with guaranteeing the self-realisation of human beings in terms of their personal, social and institutional relations.

With the overlapping of these spheres, Habermas (2000b) formulated the existing nexus between the formation of opinion and will, mediated by popular sovereignty within a public policy space and human rights, guarantors of the universal parameters of the recognition of human dignity, the private parameters of individual self-fulfilment and guaranteed equal access to the modern system of rights. The values of freedom and equality, dear to the West, are obtained through human rights and democracy.

Habermas (1997) presented an interpretation through the building of a system of rights that does not deny the recognition of human differences, revealed in the breaking down of ethical standards, resulting in "general temporal, social and objective standards of behaviour" (HABERMAS, 1997, p. 142). A democratic deliberative model is established, which is able to embrace the totality of sub-cultures, without abdicating its obligation to be based on moral standards of respect for human dignity, as well as the ethical force guaranteed by participation of the entire political community. Through the intermediation of human rights, self-determination of people and individual self-fulfilment is possible and can achieve the ideal objective of a fair and emancipated society.

Moreover, the experiences of inferiorisation, privation of rights and the degradation perpetuated by routine juridical omissions in condemnations of forms of racism in contemporary societies have transformed contemporary systems of protection into mere semblances and vehicles of the imposition of parameters and interests arising from a majority culture. With the denial of real opportunities of inclusion and recognition of differences, individuals are denied the possibility of developing their own worlds of inheritance and their internal feelings of autonomy (self-confidence, self-respect, and self-esteem) (WERLE, 2012). The disorganisation of these spheres of recognition affects the functional efficiency of social institutions themselves, leading to sickness or to the proliferation of pathologies that are 
typical of a society that fails with regard to its own normative goals (ROSENFIELD; SOBOTTKA, 2015).

For Honneth (2009), these three spheres of recognition provide the regulating levels for the development of trust, respect, and esteem, in both the individual and collective spheres; we can be autonomous, free, and equal only through the recognition of private identities. In short, according to the theory of recognition, processes of negation of the other become requisites that make the foundation of human dignity unviable, with inferiorisation due to differences in identity.

If rights are denied or omitted to particular social groups, it is implicit that they are not recognised as partners worthy of interaction. For Honneth (2009), the degeneration of socially current juridical pretensions means to be deprived of the expectation of being recognised as a subject able to form moral judgements. In this sense, it goes hand in hand with the experience of privation of rights and with loss of self-respect.

Disrespect is the lowest possible form of social levelling through which the values of individual and collectivities are denied, with deprecation of their practical-moral identities, their traditions, and ways of life. Thus, for esteem to exist, real inclusion and recognition of the other must be juridically guaranteed and be able to nurture sentiments of self-fulfilment and abstract ties of civic solidarity. Discrimination, disrespect and exclusionary processes destroy the positive identity of entire groups, leading to the establishment of pathologies, such as social suffering. Considered to be 'undesirables' within a political community, individuals suffer a block in their practical self-relation, and consequently, can end up in processes of disintegration of the social fabric.

Judicial systems and political communities, despite their differences, should also be open to processes of subversion, mediated by moral-intersubjective conflicts able to lead societies to the conquest of new universal concepts of equality and particular concepts of autonomy and personal self-fulfilment. It becomes evident that right, which seeks to isolate itself from historical and social demands and their lack of consensus, becomes a mere symbolic function, becoming unable to represent modern societies, marked by extremely complex coexistence.

Therefore, we propose a verification of possible exclusive parameters of the application of human rights in Europe. It is known that their connivance represents not merely a negation of the universalistic project of human rights - over their moral imperatives of respect for human dignity, freedom and equality—but of the negation of the ethical precepts 
of the democratic rule of law and autonomous establishment of identity (based upon experiences of reciprocal recognition).

\section{Jurisprudential analysis: Sander $v$. The United Kingdom, Velikova $v$. Bulgaria, Anguelova $v$. Bulgaria, and Nachova $v$. Bulgaria}

The triumph of the universalist principle becomes less convincing when analysed under the critical eye of social thinking, given that one witnesses simultaneously with the constant juridical-formal reiteration of the new Era of rights the continued proliferation of cases of disrespect, exclusion and/or indifference that weaken the juridical-philosophical prerogatives of the constitution of democratic rule of law. Thus, we move toward an assessment of current juridical codes and formal procedures for combating forms of intolerance of alternative groups in Europe through jurisprudential analysis of the European Court regarding Article 14 of the ECHR in regard to the prohibition of discrimination.

With regard to empirical analyses, in Sander $v$ United Kingdom (Application $\mathrm{n}^{\circ}$ 34129/96), the Asian plaintiff argued in the refutation of his conviction by the Court of Birmingham alleging that racial commentaries were expressed by two members of the jury during its deliberations, which compromised the impartiality of the proffered sentence. In his reply, the national judge merely recalled the importance of judging based upon proofs for Article 6 of the ECHR (regarding the guarantee of a just sentence) to be respected. However, considering the racially biased positions of the jury and judge, Sander appealed to the European Court, which considered the complaint to be admissible.

Based on the reported circumstances, it was stated in the transcripts of the case that the judge in Birmingham, regarding the occurrence of the crime of racism, requested the members of the jury to examine their "conscience during the evening and to so indicate in case they were unable to make a judgment based on proofs" (SANDER, 2001, p. 11). After so hearing, one juror admitted having made racial jokes but declared being sorry for such offense. Another juror, who had also been accused of such discriminatory comments remained silent. In the face of the remorse of one of the jurors, the Birmingham Court judge carried on the case, which according to the European Court represented a violation of Article 6 of the ECHR from the objective perspective.

The final deliberation of the European Court was based merely on the violation of Article 6 of the ECHR, and paradoxically, the prohibition based on the occurred racial prejudice was held to be unfounded. There was no condemnation associated with the discrimination suffered by the plaintiff during the entire judicial proceeding. For Dembour 
(2009), silence with regard to the recognition of racism in Sander amounted to being accessory to the persistent racial logic of European societies and to the creation of a jurisprudence policy unable to condemn application of a right constructed on exclusivist social bases. Where equality presupposes forms of social inclusion, discrimination results in judgments of inferiority and intolerance of differences.

Similar cases of discrimination were also repeated in the case of Velikova v Bulgaria (Application $\left.n^{\circ} 41488 / 98\right)$. In the case, the wife complained of the beating to death of her Romani husband, Mr. Tsonchev, under custody of the police, which violated the right to life (Article 2 of the ECHR), both in its substantial terms (with the real loss of life and of conditions of human dignity) as well as in its procedural dimensions (lack of effective investigation of the police in regard to the homicide). In sum, the Velikova case was based entirely on the criticism of discrimination against an ethnic minority composed of Romani people from the Republic of Bulgaria. As observed in the case records, the ethnic origin of the victim was recognised by the police during his imprisonment, and soon after his death, reports indicated that one of the police involved made explicitly pejorative comments regarding the ethnic origin of Mr. Tsonchev.

Nevertheless, the complaint of Velikova was rejected by the European Court in May 2000 due to the absence of proof pursuant to Article 14 of the ECHR, that is, due to the objective impossibility of attesting the facts in juridical terms. The admissibility of the case was based merely on the inability of the State to guarantee appropriate medical attention to Mr. Tsonchev (a violation of Article 2 of the ECHR, in its procedural aspects), and on defects of the police investigation of his death (violation of Article 13 of the ECHR). With regard to the violation of Article 14 of the ECHR, the court stated that "the level of proof demanded by the Convention is beyond any reasonable doubt. [And] that the material offered does not permit the Court to conclude without doubt that the death of Mr. Tsonchev and the lack of investigation had been motivated by racial prejudice" (VELIKOVA, 2000, p94).

Upon adopting the doctrine of beyond any reasonable doubt, the European Court transferred the onus of proof of discrimination to the victim; that is, it adopted a juridical measure equivalent to a criminal accusation within the ambit of national states. This level of proof, with regard to human rights, was never explained by the Court, being once again followed in Anguelova.

In Anguelova v Bulgaria (Application $\mathrm{n}^{\mathrm{o}}$ 38361/97), the mother of Zabchekov approached the European Court in November 1998, alleging that her son had been tortured, put to death and deprived of his freedom by Bulgarian authorities due to racial prejudice that 
involved the entire ethnic community comprising Romani people in Bulgaria. However, the Court once again stated that in spite of allegations of discrimination based on serious arguments, there was not the possibility of concluding beyond any reasonable doubt the violation of Article 14.

Despite the apparent unanimity, Judge Giovanni Bonello (2004) attached a dissenting opinion at the end of the process, stating that he considered particularly disturbing the fact that in more than 50 years of judicial opinion, the European Court had not encountered a single case of violation of the right to life or of the right to not be subjected to torture or to other degrading or inhuman treatment induced due to race, colour, creed or place of origin of the victims. He argued for the essential need of a jurisprudential review within the court based on obedience to the right of non-discrimination through legal guarantees that compromised its effectiveness in terms of the protection of human rights in Europe (Anguelova v Bulgaria, 2004, p02-13). The dissenting opinion led to a change of jurisprudence in February 2004, which was presented in the case of Nachova $v$ Bulgaria (Application $\mathrm{n}^{\circ} 43577 / 98$ and 43579/98).

In Nachova, the violation was considered to be admissible in procedural terms. That is, with regard to the ineffectiveness of the State in investigating whether racial motives had led, in fact, to the death of two young Romanis in Bulgaria. According to court records, the State failed in its duty to "investigate the existence of a possible link between racial attitudes and an act of violence [which are aspects of its] obligation" (NACHOVA, 2004, p. 161). Nevertheless, the substantive terms (of whether the deaths were motivated due to the ethnic origins of the victims) continued unchanged. As Dembour (2009, p. 229) noted, in February 2006, using the Nachova case in a case that dealt with discrimination of the entrance of Romani children in special schools, the Court recalled that its function did not consist of the assessment of the general social context or the condemnation of indirect forms of discrimination still present in European societies.

Upon delivering such justification, the Court defended the absence of responsibility in condemning forms of intolerance that still occur in social interactions, limiting itself merely to the function of declaring member states responsible or not responsible regarding violations pursuant to the ECHR, through the examination of strictly individual requests. Its posture not only discarded the historical-social development indispensable to the moral and ethical refinement of the normative substance of human rights but also used legal guarantees to not declare itself with regard to the routine relegation of particular forms of life in detriment to others. 
The notion of protection proved itself to be unable to eliminate the degradation of historically discriminated groups, with an inertial trend in treating a type of generalised social-institutional order of violations and violence. As Gallardo (2014) argued, it is necessary that "we understand that a political struggle exists whenever there are relations of domination, and that human rights are [inevitably] linked to social circumstances that strengthen the autonomy and self-esteem of each and every person [who has been] injured" (GALLARDO, 2014, p. 59).

From a critical-normative perspective, we can say that in discarding the generalised confrontation with discrimination still present in European socio-historical contexts, the Court did not seek real forms of transfers and/or redistribution of social power able to combat asymmetries that continually compromise the cumulative creation of spheres of individual and collective recognition, such as respect, esteem and self-fulfilment necessary for the attainment of the autonomy of all members of the collectivity. This scenario limits the existing imperatives of morality and ethics of fundamental human rights; it principally opens the path to more serious questions regarding the regression of the legitimately democratic rule of law model due to the possibility of the existence of traditional frameworks in the Court's final deliberations.

\section{Conclusion}

As presented briefly in this paper, according to Honnethian theory, the experiences of deprivation of rights, inferiorisation and degradation of prerogatives of recognition directly influence consolidation of the spheres of self-respect and self-esteem. Both of these, which are important for guaranteeing human honour and dignity, as well as the effectiveness of individual autonomy, a key element for constituting the normative bases of the modern system of rights are based on unrestrictive defence of basic human rights. Thus, with damage to the prerogatives of self-fulfilment of individuals and practical self-relation, it becomes unviable for us to think of egalitarian ideals, broad concepts of social justice and human emancipation, leading to the appearance of social pathologies due to a growing sentiment of injustice and oppression.

Habermas and Honneth presented a modern system of rights with an essential medium for guaranteeing social integration and confirming the real and plausible perspectives of overcoming the injustices and suffering of our reality (WERLE, 2012), in addition to be committed to the ideal of fostering social justice. Such system is developed within democratic 
processes of the development of free and collective will, with the objective of satisfying nonfulfilled historic demands of groups constantly relegated to inferiority.

Nevertheless, dubious behaviours that insist on legitimising illegitimate powers continue to proliferate, abstaining from preventing repression or violence and turning judicial systems into social institutions that support situations of domination. Legislation that isolates itself from socio-historical demands assumes the function of merely concealing contradictions and irrationalities that still permeate social institutions governed by a majority that rather than seeking justice, obstructs the paths by which it can be achieved. If the rule of law proves itself to be fragile, the democratic, collective and plural content of its political-juridical institutions also becomes particularly untrustworthy.

With the criticism of juridical insufficiencies with regard to the protection of those offended and degraded, it is timely for us to begin a reflection that considers a juridical channel of unrestricted access to rights and that does not conceal asymmetric social powers or power policies inserted within the usual logic of domination. Within this perspective, human rights could assume their function of achieving their transcendent moral content impregnated within the memory of humanity, leading to the construction of the ideals of emancipation over phenomena of the order of life in society. Therefore, "worse than the lack of success of legitimate attempts is their ambiguity, which places moral standards themselves in shadow" (HABERMAS, 2012, p. 31).

We thus contest jurisprudential practices that not only silence the arbitrariness, oppression and humiliation of groups constantly placed in an inferior position and not included in modern law but also weaken the juridical-normative order itself, from which grew the concept of the democratic rule of law, due to the maintenance of social blockage of the self-fulfilment of individuals with the continued reification of their identities. 


\section{REFERENCES}

ANGUELOVA v Bulgaria (2004) 38 EHRR 31.

BATTJES, H.; DEMBOUR, M.-B.; HART, B.; FARAHAT, A.; SPIJKERBOER, T.; WALSUM, S. The European court of human rights and immigration, European Journal of Migration and Law, 11(3), 2009, p.199-204.

DEMBOUR, M.-B. Still silencing the racism suffered by migrants, European Journal of Migration and Law, 11(3), 2009, p.221-234.

EUROPEAN Convention on Human Rights, 1950. [Online]. Available at: http://www.echr.coe.int/Documents/Convention_ENG.pdf [Accessed 28 June 2016].

EUROPEAN Court of Human Rights, 2011. Country Fact Sheets 1959 - 2010. [Online]. Available at: http://www.echr.coe.int/Documents/Country_Factsheets_1959_2010_ENG.pdf [Accessed 28 June 2016].

EUROPEAN Court of Human Rights, 2013. Factsheet - Racial discrimination. [Online]. Available at: http://www.echr.coe.int/Documents/FS_Racial_discrimination_ENG.pdf [Accessed 28 June 2016].

GIESEN, Bernhard. National Identity and Citizenship. In: EDER, Klaus; and GIESEN, Bernhard (eds.). European citizenship. Oxford: Oxford University Press, 2001, p.36-58.

HABERMAS, Jurgen. Between facts and norms. Oxford: Polity Press, 1997.

. The inclusion of the other. Edited by Ciaran Cronin and Pablo Greiff. 3rd ed. Cambridge, MA: MIT Press, 2000a.

.The postnational constellation. Cambridge: Polity Press, 2000b.

Sobre a Constituição da Europa. Translated by Denilson Werle, Luiz Repa, and Rúrion Melo. São Paulo: Unesp, 2012.

HONNETH, Axel. Luta por reconhecimento. Translated by Luiz Repa. 2nd ed., São Paulo: Editora 34, 2009.

KYMLICKA, W.; NORMAN, W. Return of the citizen, ETHICS, 104(2), 1994, p.257-289.

NACHOVA and Others v Bulgaria (2004) 39 EHRR 37.

PIOVESAN, F. Ações afirmativas da perspectiva dos direitos humanos, Cadernos de Pesquisa, 35(124), 2005, p.43-55.

ROSENFIELD, C.; SOBOTTKA, E. Justiça e instituições sociais na democracia, Civitas, 15(4), 2015, p.567-574.

SANDER v United Kingdom (2001) 31 EHRR 44. 
SANTOS, B. Uma concepção multicultural de direitos humanos, Lua Nova, 39(1), 1997, p.05-124.

Beyond abyssal thinking, REVIEW, XXX(1), 2007, p.45-89.

. Citizenship through those who are not citizens. 2012. [Online]. Available at: http://alice.ces.uc.pt/en/index.php/santos-work/a-cidadania-a-partir-dos-que-nao-saocidadaos/ [Accessed 28 June 2016].

VELIKOVA v Bulgaria (2000) 04 October 2000, ECHR 1999-V.

WERLE, Denilson. Construtivismo 'Não Metafísico' e Reconstrução 'Pós-Metafísica'. In: NOBRE, Marcos; REPA, Luís (eds.). Habermas e a Reconstrução. Campinas: Papirus, 2012, p.169-196.

Recebido em 08-07-2017;

Revisado em 27-07-2018;

Publicação em 15-12-2018. 